\title{
Perubahan Histopatologi Midgut Larva An. Vagus (Diptera : Culicidae) Akibat Paparan Ekstrak Biji Pinang
}

\author{
HISTOPATHOLOGICAL CHANGES OF ANOPHELES VAGUS LARVAE MIDGUT (DIPTERA \\ CULICIDAE) DUE TO EXPOSURES OF EXTRACT OF ARECA CATECHU'S SEEDS
}

\author{
Majematang Mading*1, Etik Ainun Rohmah², Budi Utomo ${ }^{3}$, dan Heny Arwati ${ }^{4}$. \\ ${ }^{1}$ Loka Litbangkes Waikabubak Indonesia \\ ${ }^{2}$ Institute of Tropical Disease (ITD) Universitas Airlangga \\ ${ }^{3}$ Departemen Ilmu Kesehatan Masyarakat Universitas Airlangga \\ 4Departemen Parasitologi Universitas Airlangga Indonesia \\ E-mail : majematangmading@gmail.com
}

Submitted: 31-08-2018, Revised : 28-09-2018, Revised : 17-10-2018, Accepted : 29-11-2018

\begin{abstract}
Anopheles mosquitoes are main vectors of malaria and filariasis. The continuous use of synthetic insecticides in vector control can adversely affect the quality of the environment and non-target organisms. Areca catechu L. seeds contain secondary metabolites that have bioinsecticidal effects. An experimental study was done to analyze the effects of the seed's extract on histopathological changes in the midgut of An. vagus larvae. using a post test only control group design. A.catechu L. seeds from Southwest Sumba Regency ware extracted using an ultrasonic method. The larvae used were 175 Anopheles vagus instar III or early IV that devided into seven groups where each group was exposed to an extract with a concentration of 500; 1250; 2000; 2750; 3500; 4250 and 5000 ppm and one other control group without exposure of such extract. After 24 hours of exposure, the histopathology of larval midgut was prepared, stained with Hematoxyllin-Eosin and observed using light microscopy. The results showed damage to peritripic membranes, basement membrane and midgut larval epithelial cells after 24 hours of exposure. The study concluded that Areca catechu L. seed extract can cause damage and death to the larval midgut.
\end{abstract}

Keywords: Areca catechu L., An.vagus larvae, histopathological midgut.

\begin{abstract}
Abstrak
Nyamuk Anopheles adalah vektor malaria dan filariasis. Penggunaan insektisida sintesis secara terus menerus dalam pengendalian vektor dapat berdampak buruk terhadap kualitas lingkungan dan organisme non target.. Biji buah pinang (Areca catechu L.) mengandung metabolit sekunder yang memiliki efek bioinsektisida. Tujuan penelitian ini adalah untuk menganalisis efek ekstrak biji A.catechu L. terhadap perubahan histopatologi midgut larva Anopheles vagus. Penelitian ini merupakan penelitian eksperimen laboratorium dengan rancangan post test only control group design. Biji A.catechu L. dari Kabupaten Sumba Barat Daya diekstraksi menggunakan metode ultrasonik. Larva yang digunakan adalah larva $A n$. vagus instar III atau IV awal yang dibagi menjadi tujuh kelompok dimana tiap kelompok dipaparkan pada ekstrak dengan konsentrasi 500; 1250; 2000; 2750; 3500; 4250 dan 5000 ppm dan satu kelompok lain sebagai kontrol tanpa paparan. Setiap klompok terdiri dari dua puluh lima larva. Setelah paparan 24 jam, dibuat sediaan histopatologi midgut larva, diwarnai dengan Hematoxyllin-Eosin dan diamati menggunakan mikroskop cahaya. Hasil menunjukan terjadinya kerusakan membran peritripik, membran basalis dan sel epitel midgut larva setelah 24 jam paparan. Kesempulan, ekstrak biji buah Areca catechu L. dapat menyebabkan kerusakan midgut dan menyebabkan kematian larva.
\end{abstract}

Kata kunci : Areca catechu L., larva An.vagus, histopatologi midgut 


\section{PENDAHULUAN}

Pengendalian penyakit tular vektor (nyamuk) yang paling efektif adalah dengan mengurangi populasi nyamuk pada tiap tahap siklus hidup. Pengendalian dapat dilakukan dengan menggunakan ovumidal, larvacidal, pupicidal dan adulticidal. ${ }^{1}$ Pengendalian nyamuk dewasa mengalami hambatan karena nyamuk dewasa dapat terbang, mudah mendeteksi dan menghindari semprotan bahan insektisida sintesis sehingga tindakan pengendalian sebaiknya dilakukan pada tahap pradewasa nyamuk. Tahap pradewasa habitat larva relatif terbatas dan tidak dapat menghindar dari tindakan pengendalian. ${ }^{2}$ Sebagai contoh pengendalian larva Anopheles di India berhasil dengan menggunakan bahan kimia larvasida seperti temephos, fention, malathion, cloropyrifos dan metopren. ${ }^{3}$

Mekanisme masuknya larvasida ke dalam tubuh larva adalah melalui pori-pori kulit, saluran pencernaan, dan saluran pernapasan. Larvasida masuk ke dalam tubuh larva melalui mulut larva bersama dengan makanan yang dimakan. Zat toksik masuk melalui mulut larva dan terus kebagian saluran pencernaan tengah (midgut) yang merupakan tempat terjadinya pencernaan dan penyerapan makanan. Midgut dilapisi jaringan epitel. Chapman dalam Suminar mengatakan zat toksik ini menyebabkan sel-sel epitel mengalami lisis sehingga terjadi penurunan tegangan pada permukaan selaput mukosa saluran pencernaan tengah dan selanjutnya proses pencernaan dan penyerapan makanan tidak terjadi. ${ }^{4}$

Penggunaan insektisida sintetis secara terus menerus dapat menyebabkan terakumulasinya zat beracun pada makhluk biologis masuk melalui rantai makanan. Hal ini berdampak buruk pada kualitas lingkungan dan organisme non target termasuk manusia, serta mempengaruhi keragaman hayati hewan dan tumbuhan. Disamping itu insektisida sintesis dapat merangsang peningkatan ketahanan spesies vektor (resistensi). Sebab itu perlu dicari insektisida alternatif dari bahan tanaman yang bersifat ramah lingkungan namun dapat membunuh larva dan nyamuk dewasa. ${ }^{5,6}$

Salah satu tanaman yang dapat digunakan sebagai bioinsektisida untuk pengendalian larva adalah biji pinang (Areca catechu L.).
Telah dibuktikan bahwa ekstrak tanaman ini dapat membunuh larva Culex pada konsentrasi 33,5-81,5\% setelah paparan larva uji setelah 9 jam paparan. ${ }^{7,8}$ Penelitian di Chiennai, India menunjukan bahwa daun pinang (Areca catechu L) mempunyai tingkat efektifitas larvasida terhadap larva Ae. aegypti lebih tinggi dibandingkan dengan daun tembakau (Nicotiana tabacum) dan daun siri. (Piper betle). ${ }^{9}$ Penelitian ini bertujuan untuk mempelajari perubahan histopatologi midgut larva $A n$. vagus setelah terpapar ekstrak biji Areca catechu L. Dalam penelitian ini uji coba dilakukan terhadap larva An. vagus karena spesies nyamuk ini merupakan salah satu vektor malaria dan filariasis di Indonesia. ${ }^{9,10}$

\section{BAHAN DAN METODE}

Rancangan penelitian ini adalah eksperimental laboratorium, dengan memakai kelompok kontrol dengan rancangan Post test only control group design. Penelitian ini dilakukan selama 5 bulan (Maret-Juli 2017).

\section{Ekstraksi biji pinang.}

Buah pinang yang digunakan dalam pembuatan ekstrak adalah biji buah pinang yang masih muda berumur 2 sampai 3 bulan sejak dari bunga sampai berbentuk buah pinang, kulit buah pinang berwarna hijau dan mempunyai struktur biji yang lembut. Pembuatan ekstrak dilakukan di Laboratorium SATREPS Universitas Airlangga. Ekstrak biji pinang menggunakan pelarut etanol 96\% yang dihasilkan dengan ultrasonik Sonica, setelah diuapkan dengan rotary evaporator dan di oven $40^{\circ} \mathrm{C}$ selama 24 jam berwarna coklat pekat.

\section{Larva uji dan pengujian}

Larva yang digunakan dalam penelitian ini adalah larva An.vagus instar III atau IV awal, dengan alasan bahwa larva Anopheles instar III dan IV awal telah memiliki alat tubuh yang kuat, lengkap, dan stabil terhadap pengaruh luar. Larva ini merupakan hasil koloni dari nyamuk An. vagus dewasa yang diambil dari Kabupaten Sumba Barat Daya.

Besar sampel sesuai dengan standar WHO untuk uji toksisitas yaitu sebanyak 20-25 ekor per kelompok12,13,14. Uji toksisitas menggunakan larutan uji dengan 7 kelompok konsentrasi 
ekstrak biji pinang (A.catechu L.) muda yaitu $500,1250,2000,2750,3500,4250$ dan 5000 ppm. Tiap kelompok konsentrasi ekstrak biji pinang dimasukkan terpisah ke dalam mangkuk plastik untuk perlakukan. Larva An, vagus instar III sebanyak 25 ekor diambil dengan pipet dan dimasukan ke dalam masing-masing mangkuk plastik yang berisi air sumur dan ekstrak dengan konsentrasi berbeda yang sudah disiapkan. Larva dibiarkan kontak dengan larutan uji selama 24 jam dengan 6 kali pengulangan. Terhadap larva yang mati dilakukan dengan pemeriksaan hitopatologi midgut larva.

\section{Pemeriksaan histopatologi midgut larva $\boldsymbol{A n}$. vagus.}

Pemeriksaan histopatologi dilakukan di Laboratorium Entomologi Institute of Tropical Disease (ITD) dan Laboratorium Histologi Fakultas Sains dan Teknologi Universitas Airlangga untuk melihat kerusakan saluran pencernaan larva akibat paparan ekstrak biji pinang muda. Pembuatan sediaan jaringan larva dilakukan dengan metode parafin. Blok parafin yang mengandung jaringan larva dipotong secara cross sectional menggunakan mikrotom putar dengan ketebalan $4 \mu \mathrm{m}$, lalu dibuat sediaan dan diberi pewarnaan dengan Hematoksilin-Eosin. Perubahan histopatologi midgut diamati dengan menggunakan mikroskop cahaya (Olympus, Jepang) dengan lensa objektif pembesaran 40x 6 .

\section{HASIL}

Pengamatan kerusakan histopatologi larva meliputi ada tidaknya kerusakan pada bagian membran pertiropik, sel epitel dan membran basalis (Gambar 1). Midgut larva An. vagus yang terpapar ekstrak biji pinang mengalami perubahan histopatologi. Semakin tinggi dosis ekstrak yang diberikan semakin besar kerusakan yang terjadi pada midgut larva An. vagus (Tabel 1).

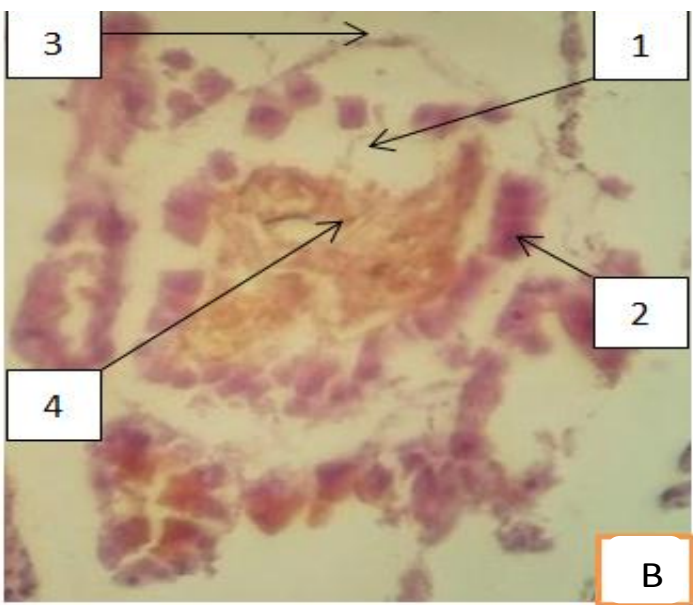

Gambar 1. Gambaran histopatologi midgut larva An. vagus. A. midgut larva yang tidak terpapar ekstrak biji pinang (kelompok kontrol); B. Midgut larva yang terpapar ekstrak biji pinang 5000 ppm. Keterangan : 1). Membran peritropik; 2) Sel epitel; 3) membran basalis; 4) inti sel epitel.

Tabel 1. Perubahan histopatologi midgut larva An. vagus berdasarkan konsentrasi ekstrak biji pinang (Arecha catechu L.)

\begin{tabular}{cll}
\hline Konsentrasi ekstrak $(\mathbf{p p m})$ & \multicolumn{1}{c}{ Tingkat kerusakan } \\
\hline 0 & a. & membran peritropik masih utuh \\
& b. & sel epitel masih utuh \\
& c. & membran basalis masih utuh \\
& d. & inti sel masih berada dalam sel epitel \\
\hline \multirow{2}{*}{500} & a. & membran peritropik masih utuh \\
& b. $\quad$ sel epitel masih utuh \\
& c. $\quad$ membran basalis masih utuh \\
& d. inti sel masih berada dalam sel epitel
\end{tabular}


1250

a. membran peritropik mengalami kerusakan
b. sel epitel masih utuh
c. membran basalis masih utuh
d. inti sel masih berada dalam sel epitel

\begin{tabular}{|c|c|c|}
\hline 2000 & $\begin{array}{l}\text { a. } \\
\text { b. } \\
\text { c. } \\
\text { d. }\end{array}$ & $\begin{array}{l}\text { membran peritropik mengalami kerusakan } \\
\text { pembengkakan pada sel epitel } \\
\text { membran basalis masih utuh } \\
\text { inti sel masih berada dalam sel epitel }\end{array}$ \\
\hline 2750 & $\begin{array}{l}\text { a. } \\
\text { b. } \\
\text { c. } \\
\text { d. }\end{array}$ & $\begin{array}{l}\text { membran peritropik mengalami kerusakan } \\
\text { pembengkakan pada sel epitel } \\
\text { membran basalis masih utuh } \\
\text { inti sel masih berada dalam sel epite }\end{array}$ \\
\hline 3500 & $\begin{array}{l}\text { a. } \\
\text { b. } \\
\text { c. } \\
\text { d. }\end{array}$ & $\begin{array}{l}\text { membran peritropik mengalami kerusakan } \\
\text { sel epitel terlepas dari membran basalis } \\
\text { membran basalis mengalami kerusakan dan terlepas dari sel epitel } \\
\text { inti sel keluar dari sel epitel }\end{array}$ \\
\hline 4250 & $\begin{array}{l}\text { a. } \\
\text { b. } \\
\text { c. } \\
\text { d. }\end{array}$ & $\begin{array}{l}\text { membran peritropik mengalami kerusakan } \\
\text { sel epitel terlepas dari membran basalis } \\
\text { membran basalis mengalami kerusakan } \\
\text { inti sel keluar dari sel epitel }\end{array}$ \\
\hline 5000 & $\begin{array}{l}\text { a. } \\
\text { b. } \\
\text { c. } \\
\text { d. }\end{array}$ & $\begin{array}{l}\text { membran peritropik mengalami kerusakan } \\
\text { sel epitel terlepas dari membran basalis } \\
\text { membran basalis mengalami kerusakan dan terlepas dari sel epitel } \\
\text { inti sel keluar dari sel epitel dan masuk kedalam lumen }\end{array}$ \\
\hline
\end{tabular}

\section{PEMBAHASAN}

Efek ekstrak biji pinang menunjukkan adanya perubahan histopatologi pada midgut larva An. vagus terutama pada membran peritropik, sel epitel dan membran basalis. Kerusakan midgut larva An.vagus kemungkinan disebabkan oleh alkaloid, flavonid, saponin, dan tanin yang merupakan metabolit sekunder yang terkandung dalam biji pinang yang memiliki sifat racun sehingga menyebabkan kematian larva An. vagus. Kerusakan morfologi pada sel epitel midgut yang kemungkinan merupakan tempat zat-zat ini diserap. ${ }^{1,15}$

Zat larvasida dari tanaman lain juga dibuktikan menyebabkan kerusakan morfologi pada sel epitel midgut1. Sejumlah senyawa seperti flavonoid, alkaloid dan saponin ${ }^{15,16}$ yang diisolasi dari tanaman $C$. siamea telah dilaporkan menunjukan aktivitas larvacidal terhadap $C x$. quinquefasciatus di Ethopia ${ }^{17}, C x$. tritaeniorhynchus di India ${ }^{18}$, dan di Afrika Barat. ${ }^{19}$

Dalam mekanismenya, senyawa metabolit sekunder yang bersifat toksik menembus membran peritrofik dan menyerang epitel midgut sehingga sel epitel mengalami kerusakan yang selanjutnya menembus membran basal dan mengakibatkan kematian larva. Sel-sel epitel midgut mengalami lisis karena adanya zat toksik yang masuk ke midgut dan menyebabkan penurunan tegangan permukaan selaput mukosa sehingga proses pencernaan dan penyerapan makanan tidak terjadi. $^{20}$

Kerusakan membran sel dan sel epitel kemungkinan disebabkan oleh senyawa flavonoid yang dapat masuk menembus kutikula larva kemudian merusak membran sel larva sehingga permeabilitas rongga badan larva menjadi rusak dan hemolimfe tidak dapat didistribusi secara sempurna serta mengakibatkan lisis tubuh larva. ${ }^{21,22}$ Semakin tinggi dosis ekstrak yang digunakan semakin banyak kerusakan yang terjadi 
pada midgut.

Kerusakan jaringan dan organ pencernaan yang disebabkan oleh senyawa alkaloid mengakibatkan menurunnya aktifitas makan larva. ${ }^{23}$ Saponin dan flavonoid mengandung tingkat toksisitas yang sangat tinggi untuk membunuh larva. ${ }^{24}$ Kandungan saponin diduga berpengaruh terhadap penurunan tegangan permukaan selaput mukosa saluran pencernaan sehingga dinding saluran pencernaan larva mengalami kerusakan6. Saponin berasa pahit, berbusa dalam air, beracun bagi binatang berdarah dingin, tidak beracun bagi binatang berdarah panas, dan mempunyai efek hemolisis (merusak sel darah merah) ${ }^{25}$

\section{KESIMPULAN}

Ekstrak biji pinang dapat mengakibatkan kerusakan midgut larva An.vagus. Makin tinggi konsentrasi ekstrak semakin besar kerusakan yang terjadi pada midgut larva An. vagus. Perubahan histopatologi midgut terjadi pada membran peritropik, membran basalis, dan sel epitel dan menyebabkan terbubuhnya larva An. vagus.

\section{UCAPAN TERIMA KASIH}

Terima kasih sebesar-besarnya disampaikan kepada Pemerintah Republik Indonesia melalui Kemeterian Kesehatan melalui Badan Pengembangan dan Pemberdayaan Sumber Daya Manusia Kesehatan yang telah memberikan bantuan dana penelitian. Terima kasih juga disampaikan kepada Kepala Laboratorium Histologi Departemen Biologi Fakultas Sains dan Teknologi Universitas Airlangga dan Kepala Loka Penelitian dan Pengembangan Pengendalian Kesehatan Waikabubak beserta staf yang telah membantu pelaksanaan penelitian.

\section{DAFTAR PUSTAKA}

1. Jiraungkoorskul K., and Wannea J. 'Larvacidal and histopathological effects of Cassia siamea leaf extract against Culex quinquesfasciatus'. Journal Tropical Life Sciences Research. 2015.; 26 (2) : 15-25.

2. Kazwaini M., Maumalay H., Waduwila R., Triana E., dan Tangkuyah J., Pemetaan sebaran vektor malaria di Provinsi Nusa
Tenggara Timur. Laporan Penelitian. 2013. Loka Litbang P2B2 Waikabubak.

3. Adnyana, ND., Triana E., Patanduk Y., Bulu AK., dan Tallan MM., Pemetaan kasus dan vektor filariasis di Pulau Sumba. Laporan Penelitian. Waikabubak : Loka Litbang P2B2 Waikabubak; 2014.

4. Killeen GF., Fillinger $U$ and Knols BGJ, Advantages of larval control for African malaria vectors: low mobility and behavioral responsiveness of immature mosquito stages allow high effective coverage, Malaria Journal. 2002; 1: 1-7.

5. ICMR. Prospects of using herbal products in the control of mosquito vectors. ICMR. Bulletin. 2003; 33: 1-12.

6. Suminar E., Pengaruh ekstrak metanol daun jeruk purut (Citrus hystrix) sebagai biolarvasida terhadap perubahan histologi midgut larva Aedes aegypti. Tesis. Surabaya : Program Studi Ilmu Kedokteran Dasar Jenjang Magister Fakultas Kedokteran Universitas Airlangga; 2014.

7. Ghosh A., Chowdhury N., and Chandra G. 'Plant extracts as potential mosquito larvicides'. Indian Journal Medical Res. 2012.; $135: 581-598$.

8. Muhmood I., Imadi SR., Shazadi K., Hakeem KR., and Gul A. Effects of Pesticides on Environment. Recearchgate. 2015: 253-269.

9. Vinayagam A. , Senthilkumar N., and Umamaheswari A, 'Larvicidal activity of some medicinal plant extracts against malaria vector Anopheles stephensi'. Research Journal of Parasitology. 2008; 3: 50-58.

10. Gassa A.,Sulaeha, dan Siswati Y. Uji keefektifan ekstrak buah pinang (Arecu catechu L.) terhadap tingkat mortalitas jentik nyamuk Culex sp. (Diptera : Culicidae). Disampaikan pada seminar ilmiah dan pertemuan tahunan PEI PFI XIX komisariat daerah. Palu, Sulawesi Selatan. 2008.

11. Tennyson, S., Arivoli, S., Raveen, R., Bobby, M., Dhinamala, K., Larvicidal Activity of Areca catechu, Nicotiana tabacum and Piper betle leaf extracts against the Dengue Vector Aedes aegypti (L.) (Diptera: Culicidae). Int. J. Res. Biol. Sci. 2012: 2, 157-160.

12. Word Health Organization. Guidelines for efficacy testing of hausehold insecticide 
products mosquito coils, vaporizer mats, liquid vaporizers, ambient emanators, and aerasol. Control of neglected tropical diseases. 2009. Jenewa.

13. Misnarni E., Armansya T., dan Hanafiah M. 'Daya larvasida ekstrak etil asetat daun kemuning (Murraya paniculata) terhadap larva Aedes aegypti' Jurnal Medika Veterinaria. $2013 ; 7$ (1) : 27-29.

14. Tennyson S., Samraj DA., Jeyasundar D., and Chalieu K. 'Larvacidal efficacy of plant oils againts the dengue vector Aedes aegypti (Diptera : Culicidae)'. Middle East Journal of Science Research. 2013; 13 (1) : 64-68.

15. Amudhan S., Begum SVH and Hebbar $\mathrm{KN}$. 'A review on phytochemical and pharmacological potential of areca catechu 1 . Seed'. International journal of pharmaceutical sciences and research. 2012; 3(11): 41514157.

16. Alli Smith YR. Determination of chemical composition of Senna siamea (Cassia leaves). Pakistan Journal of Nutrition. 2009; 8(2):119121.

17. Nagappa R. Evaluation of aqueous and ethanol extract of bioactive medicinal plant, Cassia didymobotrya (Fresenius) Irwin \& Barneby against immature stages of filarial vector, Culex quinquefasciatus Say (Diptera: Culicidae). Asian Pacific Journal of Tropical Biomedicine. 2012; 2(9):707-711.

18. Govindarajan M, Sivakumar R, Rajeswari M. Larvicidal efficacy of Cassia fistula Linn. leaf extract against Culex tritaeniorhynchus Giles and Anopheles subpictus Grassi (Diptera: Culicidae). Asian Pacific Journal of Tropical Disease. 2011;1(4):295-298.
19. Georges K, Jayaprakasam B, Dalavoy SS, Nair MG. Pest-managing activities of plant extracts and anthraquinones from Cassia nigricans from Burkina Faso. Bioresource Technology. 2008; 99(6):2037-2045.

20. Wulandari S., Arnentis, dan Rahayu S. 'Potensi getah buah pepaya (Carica papaya L.) Terhadap mortalitas larva nyamuk Aedes albopictus'. Jurnal Biogenesis. 2012; 9 (1) : 66-76.

21. Zhang WM., Bin L., Lin H., and Hai-De Z. 'Antioxidant activities of exstracts from areca (Areca catechu L.) flower, husk and seed'. African Journal of Biotecnology. 2009; 8 : 3887-3892.

22. Hastut HBS. Uji Potensi ekstrak daun dan biji pepaya (Carica papaya) sebagai larvasida terhadap mortalitas larva Anopheles sp. di Kabupaten Jayapura Papua. Tesis. 2014. Makasar : Universitas Hasanuddin Makasar; 2017.

23. Tiwow B., Widdhi B., dan Novel SK. 'Uji efek antelmintik ekstrak etanol biji pinang (Areca catechu L.) terhadap cacing Ascaris lumbricoides dan Ascaridia galli secara in vitro. Jurnal Ilmiah Farmasi UNSTRAT Manado. 2013; 2 (2) : 76-80.

24. Wahyuni D. 'New bioinsecticide granules toxin from ectract of pepaya (Carica pepaya) seed and leaf modified against Aedes aegypti larvae'. Procedia Environmental Sciences. 2014; 23 : 323-328.

25. Tomass Z., Hadis M., Taye A., Mekonnen Y., and Petros B. Larvicidal effects of Jatropha curcas L. against Anopheles arabiensis (Diptera: Culicidea). Manoma Ethiopian Journal of Science. 2011; 3 (1):52-64. 